\title{
Desulfobacter vibrioformis sp. nov., a Sulfate Reducer from a Water-Oil Separation System
}

\author{
TORLEIV LIEN $^{1 *}$ AND JANICHE BEEDER ${ }^{2}$ \\ Department of Microbiology, University of Bergen, $\mathrm{N}-5020$ Bergen, ${ }^{1}$ and Hydro Research Centre, \\ N-3901 Porsgrunn, ${ }^{2}$ Norway
}

\begin{abstract}
A mesophilic, gram-negative, vibrio-shaped, marine, acetate-oxidizing sulfate reducer (strain B54) was isolated from a water-oil separation system on a North Sea oil platform. The optimum conditions for growth were $33^{\circ} \mathrm{C}$, $\mathrm{pH} 6.8$ to 7.0 , and concentrations of $\mathrm{NaCl}$ and $\mathrm{MgCl}_{2} \cdot 6 \mathrm{H}_{2} \mathrm{O}$ of at least 1 and $0.3 \%$, respectively. Of various organic acids tested, only acetate was used as an electron and carbon source. The presence of 2-oxoglutarate:dye oxidoreductase suggests acetate oxidation via an operative citric acid cycle. Even though growth of most Desulfobacter strains (including strain B54) did not occur on hydrogen, hydrogenase was detected at low activity. The growth yields were 4.6, 13.1, and $9.6 \mathrm{~g}$ of (dry weight) cells per mol of acetate oxidized with sulfate, sulfite, and thiosulfate, respectively, as electron acceptors. Strain B54 was able to fix dinitrogen. Desulforubidin and cytochromes of the $c$ and $b$ types were present. The G+C content of the DNA was $47 \mathrm{~mol} \%$. Strain B54 is most closely related to Desulfobacter latus, with a 16S rDNA sequence similarity of 98.1\%. The DNA-DNA relatedness between them was $40.5 \%$. On the basis of differences in genotypic, phenotypic, and immunological characteristics, we propose that strain $B 54$ is a member of a new species, $D$. vibrioformis. It can be easily identified and distinguished from other Desulfobacter species by its large, vibrioshaped cells.
\end{abstract}

In 1977, Widdel and Pfennig (44) isolated the first authenticated sulfate-reducing bacterium, Desulfotomaculum acetoxidans, which is able to oxidize acetate completely to carbon dioxide. Later, several new acetate-oxidizing sulfate reducers, both mesophilic and thermophilic, were described $(4,28,43$, 45). Most of these completely oxidizing sulfate reducers are nutritionally versatile, using the oxidative $\mathrm{CO}$ dehydrogenase pathway for acetate oxidation (36). The genus Desulfobacter, however, comprises nutritionally specialized sulfate reducers with acetate as their characteristic substrate, which they oxidize via a modified citric acid cycle $(16,25)$. The genus was established in 1981 by the description of the type species Desulfobacter postgatei (43). New Desulfobacter species were isolated in 1987, and the genus description was then emended to include $\mathrm{H}_{2}$-utilizing, curved, and vibrio-shaped cells (40). Only a few Desulfobacter species, $D$. postgatei, $D$. hydrogenophilus, $D$. latus, and $D$. curvatus, have been validly described (40). Although other members of the Desulfobacter genus have been recently detected, e.g., by oligonucleotide probes, in various locations like bioreactors (33), oil field environments $(7,39)$, and photosynthetic biofilms (32), none of them has been isolated and characterized.

In this paper, we describe the general characteristics and phylogenetic relations of a marine, vibrio-shaped, sulfate-reducing bacterium belonging to the genus Desulfobacter. The strain which we describe B54 $4^{\mathrm{T}}$ [ $\mathrm{T}=$ type strain]) was enriched and isolated with acetate and sulfate in a medium inoculated with water from the oil-water separation system on an oil production platform in the North Sea. Because of significant differences in genotypic, phenotypic, and immunological properties between strain B54 $4^{\mathrm{T}}$ and validly described members of the genus Desulfobacter, we propose that strain B54 ${ }^{\mathrm{T}}$ be placed in a new species, $D$. vibrioformis.

* Corresponding author. Mailing address: University of Bergen, IM, Jahnebakken 5, N-5020 Bergen, Norway. Phone: 47-55582669. Fax: 47-55589671. E-mail: torleiv.lien@im.uib.no.
(A preliminary account of some of these results has been reported previously $[3,23]$.)

\section{MATERIALS AND METHODS}

Sources of organisms. Strain B54 $4^{\mathrm{T}}$ was isolated from a water-oil separation system on the deck of the Statfjord B oil field platform in the Norwegian sector of the North Sea. The water samples were collected after the separation (flotation cell) of produced formation water from crude oil. The temperature at the sampling point was $38^{\circ} \mathrm{C}$, and the $\mathrm{pH}$ was 7.95. D. postgatei (DSMZ 2034), D. hydrogenophilus (DSMZ 3380), D. latus (DSMZ 3381), and D. curvatus (DSMZ 3379) were from the Deutsche Sammlung von Mikroorganismen und Zellkulturen GmbH (DSMZ), Braunschweig, Germany.

Enrichment, isolation, and cultivation. Acetate-oxidizing sulfate reducers were enriched on a defined bicarbonate-buffered, sulfide-reduced marine medium (43) with $20 \mathrm{mM}$ acetate as the substrate. The medium was dispensed into $50-\mathrm{ml}$ screw-cap bottles. The bottles were inoculated with $5-\mathrm{ml}$ water samples and incubated at $30^{\circ} \mathrm{C}$ in the dark. Enrichments with sulfide concentration and turbidity increases in three consecutive passages were regarded as positive. Pure cultures were isolated by serial dilution in anoxic agar medium (41). Medium L10, which was used for routine and large-scale cultivation and characterization studies, contained (per liter of distilled water) $6.0 \mathrm{~g}$ of $\mathrm{CH}_{3} \mathrm{COONa} \cdot 3 \mathrm{H}_{2} \mathrm{O}, 7.0 \mathrm{~g}$ of $\mathrm{Na}_{2} \mathrm{SO}_{4}, 0.25 \mathrm{~g}$ of $\mathrm{NH}_{4} \mathrm{Cl}, 1.0 \mathrm{~g}$ of $\mathrm{KH}_{2} \mathrm{PO}_{4} \cdot 2 \mathrm{H}_{2} \mathrm{O}, 10 \mathrm{~g}$ of $\mathrm{NaCl}, 3.0 \mathrm{~g}$ of $\mathrm{MgCl}_{2} \cdot 6 \mathrm{H}_{2} \mathrm{O}, 0.15 \mathrm{~g}$ of $\mathrm{CaCl}_{2} \cdot 2 \mathrm{H}_{2} \mathrm{O}$, and $1 \mathrm{ml}$ of trace element solution SL-10 (42). After autoclaving, the medium was cooled under a steady flow of oxygenfree nitrogen and then reduced by adding $4 \mathrm{ml}$ of an anaerobically filter-sterilized $0.5 \mathrm{M} \mathrm{Na}_{2} \mathrm{~S} \cdot 9 \mathrm{H}_{2} \mathrm{O}$ solution per liter of medium. The $\mathrm{pH}$ was adjusted to 6.8 with $1 \mathrm{M} \mathrm{Na}_{2} \mathrm{CO}_{3}$. For dispensation of anoxic medium into (serum) bottles or culture tubes, the medium was prepared in a 3-liter Erlenmeyer flask equipped with a butyl rubber stopper and a device similar to that described by Widdel and Bak (41).

Morphology. Phase-contrast microscopy (Labophot; Nikon, Tokyo, Japan) was used for routine examinations and for photomicrography using the agar slide method (29). Platinum-palladium-shadowed cells were examined in an electron microscope (100 CX; JEOL, Tokyo, Japan).

Metabolism and physiology. Bellco tubes (no. 2047; $28 \mathrm{ml}$ ) containing $10 \mathrm{ml}$ of L10 medium with $5 \%(\mathrm{vol} / \mathrm{vol})$ inoculum were used for nutritional characterization and determination of temperature, $\mathrm{pH}$, and salinity optima. Growth was determined by measuring the increase in optical density at $600 \mathrm{~nm}$.

Sulfide was measured by the method of Cord-Ruwisch (11). Acetate was assayed by using a Varian high-performance liquid chromatograph (HPLC) equipped with a Perkin-Elmer LC-75 spectrophotometric detector and an Aminex HPX-87H column (Bio-Rad, Richmond, Calif.).

Pigments. Cytoplasmic and membrane fractions were made from $8 \mathrm{~g}$ (wet mass) of cells as described previously (34). The cytoplasmic fraction was dialyzed against $10 \mathrm{mM}$ Tris- $\mathrm{HCl}$ buffer, $\mathrm{pH} 7.6$, and proteins were separated on a DEAE-cellulose column as described by Samain et al. (35). The spectrum of the 
various eluent fractions was recorded and checked for peaks characteristic of desulforubidin (22). Membrane-bound pigments were extracted from the membrane fraction with Triton X-100 $(0.5 \%, \mathrm{vol} / \mathrm{vol})$ as described previously (34). Cytochromes were identified in this extract and in the DEAE-cellulose eluate by spectroscopy of dithionite-reduced samples (37).

Serology. Polyclonal antiserum against strain $\mathrm{B} 54^{\mathrm{T}}$ was produced as described previously (10). Antigens were characterized by Western immunoblotting of sodium dodecyl sulfate (SDS)-soluble whole-cell extracts. SDS-polyacrylamide gel electrophoresis (SDS-PAGE) of the whole-cell extracts was carried out as described by Laemmli (21), with $12.5 \%$ (wt/vol) and $4.5 \%$ (wt/vol) polyacrylamide in the separation and stacking gels, respectively. The PAGE was run at 190 $\mathrm{V}$ in a Mini Protean II Dual Slab Cell (Bio-Rad). After SDS-PAGE, the gels were stained with Coomassie brilliant blue (R-250; Serva). Unstained gels were immunoblotted as described by Burnette $(8)$, by using a Mini Trans Blot Cell (Bio-Rad).

Enzyme assays. Preparation of cell extract was performed in an anoxic chamber or under flushing with oxygen-free gas. All assays were performed under strictly anaerobic conditions at $30^{\circ} \mathrm{C}$. Carbon monoxide dehydrogenase and 2oxoglutarate dehydrogenase were assayed as described previously (2). Hydrogenase activity was measured as $\mathrm{H}_{2}$ consumption by monitoring benzyl viologen dye reduction at $555 \mathrm{~nm}$ in $100 \mathrm{mM}$ Tris $\mathrm{HCl}$ buffer, $\mathrm{pH} 8.5$, and as $\mathrm{H}_{2}$ evolution from dithionite-reduced methyl viologen (17). Sulfite reductase was assayed with reduced methyl viologen as the electron donor (26). Nitrogenase activity was measured by using the acetylene reduction method (15). Protein was measured by the Bradford method (6).

DNA analyses. The $\mathrm{G}+\mathrm{C}$ content of DNA (isolated as described by Beji et al. [5]) was determined after enzymatic digestion and HPLC separation of nucleosides (24). For the DNA-DNA hybridization studies, DNA was isolated by chromatography on hydroxyapatite by the procedure of Cashion et al. (9). The hybridization was carried out as described by De Ley et al. (12), with the modifications described by HuB et al. (18), using a Gilford System 2600 spectrophotometer equipped with a Gilford 2527-R thermoprogrammer and plotter. Renaturation rates were computed with the TRANSFER.BAS program (19).

16S rDNA sequencing. Genomic DNA extraction, PCR-mediated amplification of the 16S rDNA, and purification of PCR products were done as previously described $(30,31)$. Purified PCR products were sequenced by using a Taq DyeDeoxy terminator cycle sequencing kit (Applied Biosystems, Foster City, Calif.) as recommended by the manufacturer. An Applied Biosystems 373A DNA sequencer was used for electrophoresis of the sequence reaction products. The 16S rDNA sequence was manually aligned against representative sequences of members of the delta subclass of Proteobacteria. Pairwise evolutionary distances were computed by using the correction of Jukes and Cantor (20). The least-squares distance of De Soete (13) was used to construct a phylogenetic dendrogram from distance matrices. The hybridization and sequence analyses were carried out at the Identification Service of the DSMZ by F. A. Rainey.

Nucleotide sequence accession number. The sequence of the 16S rDNA of strain B54 ${ }^{\mathrm{T}}$ has been deposited in the GenBank database under accession number $\mathrm{U} 12254$.

\section{RESULTS}

Enrichment and isolation. Enrichment cultures with acetate produced sulfide after 6 to 8 days of incubation at $30^{\circ} \mathrm{C}$. The enrichments were subcultured, and a large, vibrio-shaped bacterium became dominant in several of the cultures after three consecutive passages. This strain, designated B54 ${ }^{\mathrm{T}}$, was isolated in pure culture.

Morphology. The cells of strain $\mathrm{B} 54^{\mathrm{T}}$ were vibrio shaped, 1.9 to 2.3 by 4.5 to $8 \mu \mathrm{m}$ in size, and nonmotile or motile with a single polar flagellum (Fig. 1). They were usually single or in pairs and sometimes arranged in chains but did not form aggregates. Electron micrographs of thin sections of cells revealed a gram-negative cell wall structure (not shown).

Pigments. The cytoplasmic fraction was subjected to anionexchange chromatography on a DEAE-cellulose column. A reddish brown fraction eluted from the column was identified as desulforubidin by absorption maxima at 392,545 , and 580 $\mathrm{nm}$ and sulfite reductase activity. Dithionite-reduced spectra of a reddish fraction revealed absorption maxima at 416,522 , and $552 \mathrm{~nm}$, indicating the presence of $c$-type cytochromes. Cytochromes of the $b$ type (absorption maxima at 424, 526, and 558 $\mathrm{nm})$ were extracted from the membrane fraction with $0.5 \%$ (vol/vol) Triton X-100.

Physiology. Temperature and $\mathrm{pH}$ optima and other growth characteristics are given in Table 1 . Strain $\mathrm{B} 54^{\mathrm{T}}$ grew between
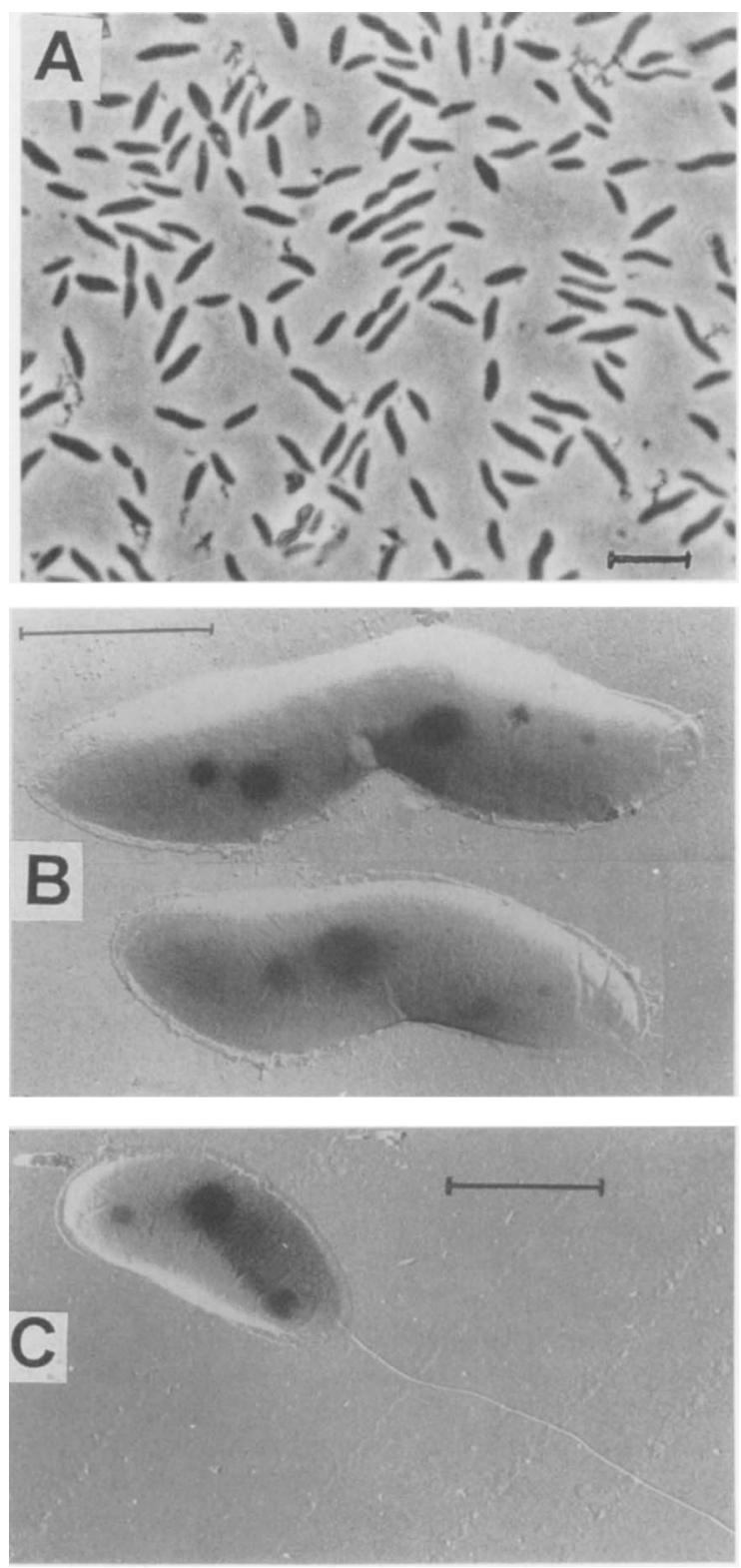

FIG. 1. Morphology of strain B54 ${ }^{\mathrm{T}}$. (A) Phase-contrast micrograph of ceils. $\mathrm{Bar}, 10 \mu \mathrm{m}$. (B and C) Electron micrographs of platinum-palladium (diagonal)shadowed cells, one of which (C) has a monopolar flagellum. Bars, $2 \mu \mathrm{m}$.

5 and $38^{\circ} \mathrm{C}$. The best growth was obtained with phosphatebuffered L10 medium. The isolate required at least $0.3 \%$ (wt/ vol) $\mathrm{Mg}_{2} \mathrm{Cl} \cdot 6 \mathrm{H}_{2} \mathrm{O}$ and $1 \%$ (wt/vol) $\mathrm{NaCl}$ in the medium. Growth occurred equally well between 1 and $5 \%$ (wt/vol) $\mathrm{NaCl}$. The isolate is able to fix dinitrogen, since it grew well in ammonia-free medium in the presence of $\mathrm{N}_{2}$, and the cells from these cultures were positive for nitrogenase activity by the acetylene reduction test.

More than 30 different substrates were tested as carbon and/or energy sources and potential electron acceptors. The results showed that only acetate was used as a carbon and energy source with sulfate, sulfite, and thiosulfate as alternative electron acceptors. Acetate was oxidized to $\mathrm{CO}_{2}$. The growth yields were $4.6,13.1$, and $9.5 \mathrm{~g}$ of cell dry weight per mol of oxidized acetate with sulfate, sulfite, and thiosulfate, 
TABLE 1. Comparison of characteristics of $D$. vibrioformis and validly described Desulfobacter species

\begin{tabular}{|c|c|c|c|c|c|}
\hline Characteristic & $\begin{array}{l}\text { D. vibrioformis } \\
\text { B54 }\end{array}$ & D. latus $^{a}$ & D. curvatus $^{a}$ & D. hydrogenophilus ${ }^{a}$ & D. postgatei ${ }^{b}$ \\
\hline Cell shape & Vibrioid & Oval, elongated & Vibrioid & Oval, elongated & Rod to ellipsoid \\
\hline \multicolumn{6}{|l|}{ Cell sizes $(\mu \mathrm{m})$} \\
\hline Width & $1.9-2.5$ & $1.6-2.4$ & $0.5-1$ & $1-1.3$ & $1-1.5$ \\
\hline Length & $4.5-8$ & $4-7$ & $1.7-3.5$ & $2-3$ & $1.7-2.3$ \\
\hline Motility & + & \pm & + & - & \pm \\
\hline Temp optimum $\left({ }^{\circ} \mathrm{C}\right)$ & 33 & $29-32$ & $28-31$ & 29-32 & 32 \\
\hline pH optimum & $6.8-7.0$ & $7.0-7.3$ & $6.8-7.2$ & $6.6-7.0$ & 7.3 \\
\hline $\begin{array}{l}\text { Salinity range }\left(\% \mathrm{NaCl}, \mathrm{MgCl}_{2}\right. \\
\left.\quad 6 \mathrm{H}_{2} \mathrm{O}\right)\end{array}$ & $1-5, \geq 0.3$ & $2,0.3$ & $\geq 0.7, \geq 0.13$ & $2,0.3$ & $\geq 0.5, \geq 0.1$ \\
\hline Vitamin requirement(s) & None & Biotin, thiamine & Biotin & Biotin, $p$-aminobenzoate & Biotin, $p$-aminobenzoate \\
\hline Shortest doubling time $(\mathrm{h})$ on acetate & 20 & 21 & 21 & 18 & 20 \\
\hline $\mathrm{G}+\mathrm{C}$ content of DNA (mol\%) & 47 & 43.8 & 46.1 & 44.6 & 45.9 \\
\hline \multicolumn{6}{|l|}{ Electron donors } \\
\hline Acetate & + & + & + & + & + \\
\hline $\mathrm{H}_{2}$ & - & - & - & + & - \\
\hline Ethanol & - & - & + & + & - \\
\hline Pyruvate & - & - & + & + & - \\
\hline \multicolumn{6}{|l|}{ Electron acceptors } \\
\hline Sulfate & + & + & + & + & + \\
\hline Sulfite & + & - & + & + & + \\
\hline Thiosulfate & + & - & + & + & + \\
\hline
\end{tabular}

${ }^{a}$ Data from reference 40 .

${ }^{b}$ Data from reference 43 .

respectively. No dismutation of sulfite and thiosulfate was observed.

Cell extract of strain B54 ${ }^{\mathrm{T}}$ contained no carbon monoxide dehydrogenase activity but had a specific activity of 2-oxoglutarate dehydrogenase of $0.53 \mu \mathrm{mol} \cdot \mathrm{min}^{-1} \cdot \mathrm{mg}$ of protein ${ }^{-1}$, which indicates the presence of an operative citric acid cycle. The activities of hydrogenase in intact cells were $16 \pm 2$ and $7 \pm 1 \mathrm{nmol} \cdot \min ^{-1} \cdot \mathrm{mg}$ of protein ${ }^{-1}$ for $\mathrm{H}_{2}$ consumption and $\mathrm{H}_{2}$ production, respectively. Hydrogen consumption activity was found in the whole cells and in the cytoplasmic and membrane fractions of all of the Desulfobacter species tested. The highest activity, $350 \mathrm{nmol} \cdot \min ^{-1} \cdot \mathrm{mg}$ of protein ${ }^{-1}$, was assayed with intact cells of $D$. curvatus.

Whole-cell protein patterns. Although the Desulfobacter species have proteins in common, e.g., in the molecular mass range of 45 to $90 \mathrm{kDa}$, strain $\mathrm{B} 54^{\mathrm{T}}$ contained specific protein bands, e.g., at 18 to 20 and at $32 \mathrm{kDa}$, that differentiated it from the other Desulfobacter species (Fig. 2A).

Serological characterization. An antigen band with a molecular mass of $60 \mathrm{kDa}$ was found in all of the Desulfobacter species tested (Fig. 2B). However, the immunoblotting demonstrated serological differences between the Desulfobacter species. Strain $\mathrm{B} 54^{\mathrm{T}}$ had several unique antigen bands, especially in the lower-molecular-mass range, which discriminate it from the other Desulfobacter species.

DNA base composition. The $\mathrm{G}+\mathrm{C}$ content of DNA from strain $\mathrm{B} 54^{\mathrm{T}}$ was $47.4 \pm 0.1 \mathrm{~mol} \%$ as determined by the chemical method. The results also revealed that $1 \%$ of the adenines and $2 \%$ of the cytosines are methylated.

Phylogeny. 16S rDNA sequence analyses of strain B54 showed it to group within the delta subclass of Proteobacteria. Figure 3 shows the relationship of strain $B 54^{\mathrm{T}}$ to the main lines within the sulfate-reducing members of the delta subclass. It is clear from the phylogenetic dendrogram that strain $\mathrm{B} 54^{\mathrm{T}}$ is most closely related to the genus Desulfobacter. The similarity of the $16 \mathrm{~S}$ rDNA sequence of strain $\mathrm{B} 54^{\mathrm{T}}$ to those of the validly described species of the genus Desulfobacter is in the range of 96.2 to $98.1 \%$, and $D$. latus is the most closely related species.

DNA-DNA homology. The DNA-DNA homology of strain $\mathrm{B} 54^{\mathrm{T}}$ and $D$. latus was examined; the hybridization value was $40.5 \%$.

\section{DISCUSSION}

North Sea formation water contains both acetate (1) and sulfate (4). Hence, mesophilic, acetate-oxidizing sulfate reducers are likely to be active in the part of this separation system with moderate and low temperature ranges. The finding of hydrogenase activity in all of the Desulfobacter species tested was unexpected, since only $D$. hydrogenophilus are able to grow with hydrogen (40). It may be that under certain growth conditions, the other Desulfobacter spp. are also able to utilize hydrogen. Furthermore, the observed low hydrogenase activity for hydrogen production may be connected to the modified citric acid cycle in Desulfobacter spp. with ferredoxin as an electron acceptor (25).

Strain B54 ${ }^{\mathrm{f}}$ was identified as a member of the genus Desulfobacter on the basis of phenotypic characteristics, e.g., the ability to grow solely on acetate as a substrate in a dissimilatory sulfate reduction to sulfide. This identification was confirmed by $16 \mathrm{~S}$ rDNA sequence analyses, which showed that strain $\mathrm{B} 54^{\mathrm{T}}$ is most closely related to $D$. latus (level of sequence similarity, 98.1\%). However, $16 \mathrm{~S}$ rDNA sequence analyses are unable to separate closely related species with similarity levels of $97 \%$ or higher. Their relationships are best determined by phenetic and genetic similarities $(14,27,38)$. Strain $B 54^{\mathrm{T}}$ differs phenotypically, serologically, and genetically from the other validly described Desulfobacter species. First, strain B54 ${ }^{\mathrm{T}}$ has a distinct morphology, with large vibrio-shaped (curved) 


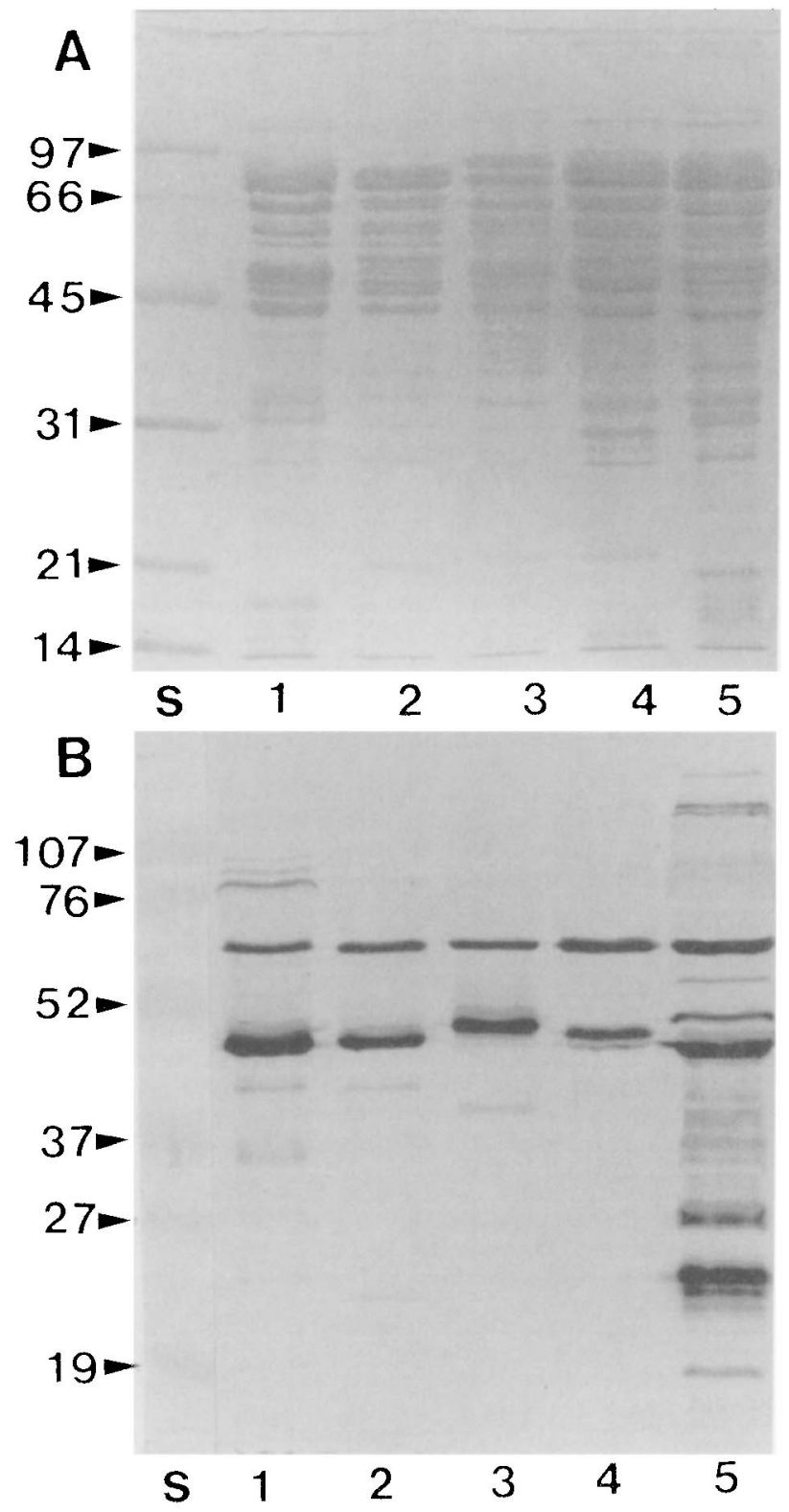

FIG. 2. Protein patterns (A) and immunoblotting with anti-B54 $4^{\mathrm{T}}$ antibody (B) after SDS-PAGE of SDS-soluble whole-cell extracts of D. postgatei (lanes 1), $D$. curvatus (lanes 2), D. hydrogenophilus (lanes 3), D. latus (lanes 4), and strain $\mathrm{B} 54^{\mathrm{T}}$ (lanes 5). Molecular masses of standards (lanes S) are indicated (in kilodaltons) on the left.

cells that are frequently paired. Second, strain $B 54^{\mathrm{T}}$ has no vitamin requirement. In contrast to $D$. latus, it utilizes sulfite and thiosulfate as alternative electron acceptors (Table 1). So does the marine, vibrio-shaped species $D$. curvatus, but it grows best with ethanol (40). Third, the protein profile and immunological properties of $\mathrm{B} 54^{\mathrm{T}}$ are different from those of the other Desulfobacter species. Fourth, strain B54 ${ }^{\mathrm{T}}$ has a slightly higher $\mathrm{G}+\mathrm{C}$ content than the other Desulfobacter species. Finally, the level of DNA-DNA hybridization of $40.5 \%$ between strain $\mathrm{B} 54^{\mathrm{T}}$ and $D$. latus is, according to the current criterion (38), too low for these organisms to be considered members of the same species. Therefore, it appears necessary to establish a

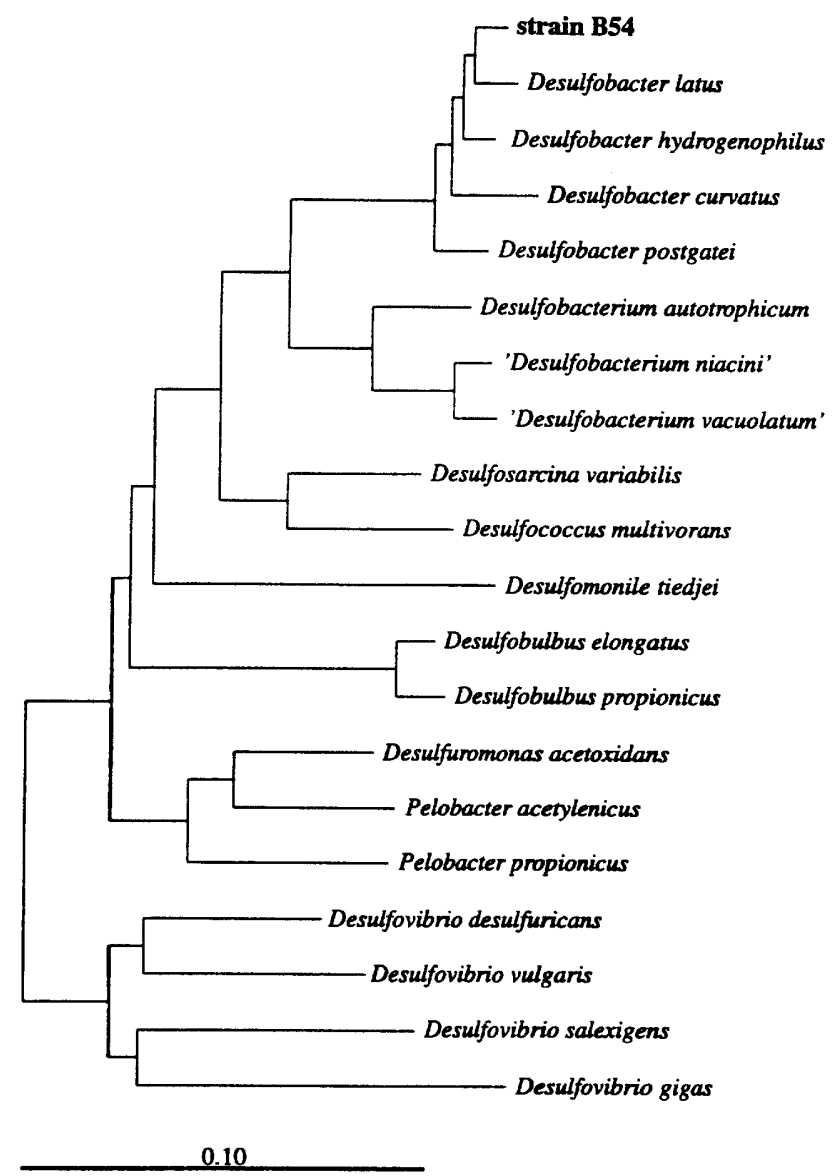

FIG. 3. Phylogenetic dendrogram based on 16S rDNA sequence comparison, indicating the positions of strain $\mathrm{B} 54^{\mathrm{T}}$ within the radiation of the sulfate-reducing bacteria of the delta subclass of Proteobacteria. Bar, 10 nucleotide changes per 100 nucleotides.

new species, for which we propose the name Desulfobacter vibrioformis.

Description of Desulfobacter vibrioformis sp. nov. Desulfobacter vibrioformis (vi.bri.o.for' mis. L. v. vibrio, vibrate; M. L. n. vibrio, that which vibrates, a generic name; L. adj. suffix -formis, -like, of the shape of; vibrioformis, vibrio shaped). Vibrio-shaped cells, 1.9 to 2.3 by 4.5 to $8 \mu \mathrm{m}$, usually single or in pairs and sometimes in chains. Do not form aggregates. Nonmotile or motile with a single polar flagellum. Reduces sulfate, sulfite, and thiosulfate. Acetate is the only electron donor and carbon source used. Able to fix $\mathrm{N}_{2}$. No vitamins but at least $1 \% \mathrm{NaCl}$ and $0.3 \% \mathrm{MgCl} \cdot 6 \mathrm{H}_{2} \mathrm{O}$ are required. Growth occurs equally well between 1 and $5 \% \mathrm{NaCl}$ in the medium. The temperature range for growth is 5 to $38^{\circ} \mathrm{C}$; the optimum is $33^{\circ} \mathrm{C}$. The optimum $\mathrm{pH}$ is 6.8 to 7.0 . Desulforubidin, cytochromes $c$ and $b$ are present. The DNA base composition is 47 mol\% $\mathrm{G}+\mathrm{C}$ (as determined by HPLC). Isolated from production water from an oil separation system on a North Sea oil production platform. The type strain is B54 ${ }^{\mathrm{T}}$ (= DSMZ 8776).

\section{ACKNOWLEDGMENTS}

We are indebted to the Norwegian Research Council for financial support, to the Norwegian oil company STATOIL for sample collection, and to Terje Torsvik for antiserum.

Part of this work was done at The University of Georgia, Athens, where we want to thank H. D. Peck, Department of Biochemistry, for 
use of the laboratory facilities; M. Mesbah and W. B. Whitman, Department of Microbiology, The University of Georgia, for determination of $\mathrm{G}+\mathrm{C}$ content; and C. Kelloes, Central Electron Microscopy, for electron micrography.

\section{REFERENCES}

1. Barth, T., and M. Riis. 1992. Interactions between organic anions in formation waters and reservoir mineral phases. Org. Geochem. 19:455-482.

2. Beeder, J., R. K. Nilsen, J. T. Rosnes, T. Torsvik, and T. Lien. 1994. Archaeoglobus fulgidus isolated from hot North Sea oil field waters. Appl. Environ. Microbiol. 60:1227-1231.

3. Beeder, J., T. Lien, and T. Torsvik. 1990. Immunological properties of Desulfobacter, p. 359-360. In J. P. Bélaich, M. Bruschi, and J. L. Garcia (ed.), Microbiology and biochemistry of strict anaerobes involved in interspecies hydrogen transfer. Plenum, New York, N.Y.

4. Beeder, J., T. Torsvik, and T. Lien. 1995. Thermodesulforhabdus norvegicus gen. nov., sp.nov., a novel thermophilic sulfate-reducing bacterium from oil field water. Arch. Microbiol. 164:331-336.

5. Beji, A., D. Izard, F. Gavini, H. Leclerc, M. Leseine-Delstanche, and J. Krembel. 1987. A rapid chemical procedure for isolation and purification of chromosomal DNA from gram-negative bacilli. Anal. Biochem. 162:18-23.

6. Bradford, M. M. 1976. A rapid and sensitive method for the quantitation of microgram quantities of protein utilizing the principle of protein-dye binding. Anal. Biochem. 72:248-254.

7. Brink, D. E., I. Vance, and D. C. White. 1994. Detection of Desulfobacter in oil field environments by non-radioactive DNA probes. Appl. Microbiol. Biotechnol. 42:469-475.

8. Burnette, W. N. 1981. "Western blotting": electrophoretic transfer of proteins from SDS-PAGE to unmodified nitrocellulose and radiographic detection with antibody and radioiodinated protein A. Anal. Biochem. 195:112203.

9. Cashion, P., M. A. Holder-Franklin, J. McCully, and M. Franklin. 1977. A rapid method for the base ratio determination of bacterial DNA. Anal. Biochem. 81:461-466.

10. Christensen, B., T. Torsvik, and T. Lien. 1992. Immunomagnetically captured thermophilic sulfate-reducing bacteria from North Sea oil field waters. Appl. Environ. Microbiol. 58:1244-1248.

11. Cord-Ruwisch, R. 1985. A quick method for the determination of dissolved and precipitated sulfides in cultures of sulfate-reducing bacteria. J. Microbiol. Methods 5:83-91.

12. De Ley, J., H. Cattoir, and A. Reynarts. 1970. The quantitative measurement of DNA hybridization from renaturation rates. Eur. J. Biochem. 12:133-142.

13. De Soete, G. 1983. A least squares algorithm for fitting trees to proximity data. Psychometrika 48:621-626.

14. Fox, G. E., J. D. Wisotzkey, and P. Jurtshuk, Jr. 1992. How close is close: 16S rRNA sequence identity may not be sufficient to guarantee species identity. Int. J. Syst. Bacteriol. 42:166-170.

15. Gerhardt, P., R. G. E. Murray, W. Wood, and N. R. Krieg (ed.). 1994. Methods for general and molecular bacteriology, p. 635. American Society for Microbiology, Washington, D.C.

16. Hansen, T. A. 1994. Metabolism of sulfate-reducing prokaryotes. Antonie van Leeuwenhoek 66:165-185.

17. He, S.-H., S. B. Woo, D. V. DerVartanian, J. Le Gall, and H. D. Peck, Jr. 1989. Effects of acetylene on hydrogenases from the sulfate reducing and methanogenic bacteria. Biochem. Biophys. Res. Commun. 161:127-133.

18. Huß, V. A. R., H. Festl, and K. H. Schleifer. 1983. Studies on the spectrophotometric determination of DNA hybridization from renaturation rates. Syst. Appl. Microbiol. 4:184-192.

19. Janke, K.-D. 1992. BASIC computer program for evaluation of spectroscopic DNA renaturation data from GILFORD SYSTEM 2600 spectrophotometer on a PC/XT/AT type personal computer. J. Microbiol. Methods 15:61-73.

20. Jukes, T. H., and C. R. Cantor. 1969. Evolution of protein molecules, p. 21-132. In H. N. Munro (ed.), Mammalian protein metabolism. Academic Press, Inc., New York, N.Y.

21. Laemmli, U. K. 1970 . Cleavage of structural proteins during the assembly of the head of bacteriophage T4. Nature (London) 227:680-685.

22. Lee, J., C. Yi, J. LeGall, and H. D. Peck. 1973. Isolation of a new pigment, desulforubidin, from Desulfovibrio desulfuricans (Norway strain) and its role in sulfite reduction. J. Bacteriol. 115:453-455.

23. Lien, T., and T. Torsvik. 1990. Hydrogenase in Desulfobacter, p. 519-520. In J. P. Bélaich, M. Bruschi, and J. L. Garcia (ed.), Microbiology and biochemistry of strict anaerobes involved in interspecies hydrogen transfer. Plenum, New York, N.Y.

24. Mesbah, M., U. Premachandran, and W. B. Whitman. 1989. Precise measurement of the $\mathrm{G}+\mathrm{C}$ content of deoxyribonucleic acid by high-performance liquid chromatography. Int. J. Syst. Bacteriol. 39:159-167.

25. Möller, D., R. Schauder, G. Fuchs, and R. K. Thauer. 1987. Acetate oxidation to $\mathrm{CO}_{2}$ via a citric acid cycle involving an ATP-citrate lyase: a mechanism for the synthesis of ATP via substrate level phosphorylation in Desulfobacter postgatei growing on acetate and sulfate. Arch. Microbiol. 148:202-207.

26. Möller-Zinkhan, D., and R. K. Thauer. 1988. Membrane-bound NADPH dehydrogenase- and ferredoxin:NADP oxidoreductase activity involved in electron transport during acetate oxidation to $\mathrm{CO}_{2}$ in Desulfobacter postgatei. Arch. Microbiol. 150:145-154.

27. Nilsen, R. K., T. Torsvik, and T. Lien. 1996. Desulfotomaculum thermocisternum sp. nov., a sulfate reducer isolated from a hot North Sea oil reservoir. Int. J. Syst. Bacteriol. 46:397-402.

28. Oude Elferink, S. J. W. H., R. N. Maas, H. J. M. Harmsen, and A. J. M Stams. 1995. Desulforhabdus amnigenus gen. nov. sp. nov., a sulfate reduce isolated from anaerobic granular sludge. Arch. Microbiol. 164:119-124.

29. Pfennig, N., and S. Wagner. 1986. An improved method of preparing wet mounts for photo-micrographs of microorganisms. J. Microbiol. Methods 4:303-306.

30. Rainey, F. A., and E. Stackebrandt. 1993. 16S rDNA analysis reveals phylogenetic diversity among the polysaccharolytic clostridia. FEMS Microbiol. Lett. 113:125-128.

31. Rainey, F. A., M. Dorsch, H. W. Morgan, and E. Stackebrandt. 1992. $16 \mathrm{~S}$ rDNA analysis of Spirochaeta thermophila: position and implications for the systematics of the order Spirochaetales. Syst. Appl. Microbiol. 16:224-226.

32. Ramsing, N. B., M. Kuhl, and B. B. Jörgensen. 1993. Distribution of sulfatereducing bacteria, $\mathrm{O}_{2}$ and $\mathrm{H}_{2} \mathrm{~S}$ in photosynthetic biofilms determined by oligonucleotide probes and microelectrodes. Appl. Environ. Microbiol. 59: 3840-3849.

33. Raskin, L., D. Zheng, M. E. Griffin, P. G. Stroot, and P. Misa. 1995. Characterization of microbial communities in anaerobic bioreactors using molecular probes. Antonie van Leeuwenhoek 68:297-308.

34. Rosnes, J. T., T. Torsvik, and T. Lien. 1991. Spore-forming thermophilic sulfate-reducing bacteria isolated from North Sea oil field waters. Appl. Environ. Microbiol. 57:2302-2307.

35. Samain, E., H. C. Dubourguier, and G. Albagnac. 1984. Isolation and characterization of Desulfobulbus elongatus sp. nov. from mesophilic industrial digester. Syst. Appl. Microbiol. 5:391-401.

36. Schauder, R., A. Preuss, M. Jetten, and G. Fuchs. 1989. Oxidative and reductive acetyl CoA/carbon monoxide pathway in Desulfobacterium autotrophicum. 2. Demonstration of the enzymes of the pathway and comparison of CO dehydrogenase. Arch. Microbiol. 151:84-89.

37. Smith, L. 1978. Bacterial cytochromes and their spectral characterization. Methods Enzymol. 53:202-212.

38. Stackebrandt, E., and B. M. Goebel. 1994. Taxonomic note: a place for DNA-DNA reassociation and 16S rRNA sequence analysis in the present species definition in bacteriology. Int. J. Syst. Bacteriol. 44:846-849.

39. Voordouw, G., S. M. Armstrong, M. F. Reimer, B. Fouts, A. J. Telang, Y. Shen, and D. Gevertz. 1996. Characterization of 16S rRNA genes from oil field microbial communities indicates the presence of a variety of sulfatereducing, fermentative, and sulfide-oxidizing bacteria. Appl. Environ. Microbiol. 62:1623-1629.

40. Widdel, F. 1987. New types of acetate-oxidizing, sulfate-reducing Desulfobacter species, D. hydrogenophilus sp. nov., D. latus sp. nov., and D. curvatus sp. nov. Arch. Microbiol. 148:286-291.

41. Widdel, F., and F. Bak. 1992. Gram-negative mesophilic sulfate-reducing bacteria, p. 3352-3378. In A. Balows, H. G. Trüper, M. Dworkin, W. Harder, and K.-H. Schleifer (ed.), The prokaryotes. A handbook on the biology of bacteria: ecology, physiology, isolation, identification, applications, 2nd ed. Springer-Verlag, New York, N.Y

42. Widdel, F., G. W. Kohring, and F. Mayer. 1983. Studies of dissimilatory sulfate-reducing bacteria that decompose fatty acids. III. Characterization of the filamentous gliding Desulfonema limicola gen. nov. and sp. nov. and Desulfonema magnum sp. nov. Arch. Microbiol. 129:286-294.

43. Widdel, F. and N. Pfennig. 1981. Studies of dissimilatory sulfate-reducing bacteria that decompose fatty acids. I. Isolation of sulfate-reducing bacteria enriched with acetate from saline environments. Description of Desulfobacter postgatei gen. nov. and sp. nov. Arch. Microbiol. 129:395-400.

44. Widdel, F., and N. Pfennig, 1977. A new anaerobic, sporing, acetate-oxidiz ing, sulfate-reducing bacterium, Desulfotomaculum (emend.) acetoxidans. Arch. Microbiol. 112:119-122

45. Widdel, F and T. A. Hansen. 1992. The dissimilatory sulfate- and sulfurreducing bacteria, p. 583-624. In A. Balows, H. G. Trüper, M. Dworkin, W. Harder, and K.-H. Schleifer (ed.), The prokaryotes: a handbook on the biology of bacteria: ecology, physiology, identification, applications, 2nd ed. Springer-Verlag, New York, N.Y. 